\title{
Clean Ecological Methods of Struggle with Urban Pests
}

\author{
Valentin Borisovich Sapunov \\ Department of Control, Sankt-Petersburg State Agricultural University, St. Petersburg, Russia
}

\author{
Email address: \\ sapunov@rshu.ru
}

\section{To cite this article:}

Valentin Borisovich Sapunov. Clean Ecological Methods of Struggle with Urban Pests. American Journal of Modern Physics. Vol. 10, No. 2, 2021, pp. 26-29. doi: 10.11648/j.ajmp.20211002.11

Received: August 8, 2020; Accepted: August 27, 2020; Published: April 23, 2021

\begin{abstract}
Advance of pest diversity on urban area is reality of modern time. Actual biological technologies are unable to prevent this process. Sometimes struggle leads to negative results in particular under use of chemical pesticides. Use of clean ecological methods must be strategy of nearest future. The basis of such a technology must be imitation of wild nature processes. There are 4 groups of such a technique. They are: ecological, genetical, chemical-and-ecological, physical-andecological. Ecological ones are based on natural intra species relations. They are: competition, host-parasites and predatorprey. The use of competition is only way to complete suffocation of unprofitable species by less dangerous one. Genetically methods are based on selection and gene engineering. Chemical-and-ecological methods are based on use of natural biological activity compounds of their analogs. Such compounds are: hormones, anti hormones, biological toxins, attractants and repellents. Ecological-and-physical methods are based on use of natural fields such as acoustical (sound, ultrasound, infrasound) and electromagnetic. Only composition and rotation of all the methods may become the basis for effective control of urban pest populations.
\end{abstract}

Keywords: Ecology, Urban Biocenosis, Agrocenosis, Pest Management

\section{Introduction}

Beginning of modern century marked the onset of a wide number of pests in urban biocenosis and agrocenosis $[1,2]$. This can be seen as a reaction to the growth of the biota of anthropogenic pressure, which took place in the second half of the twentieth century. Development and mass adoption of pest management practices had a negative environmental impact. They are connected to contamination from pesticides and with the activation of the genetic and evolutionary responses of pest populations to deal with them. Sometimes active pest had results opposite to the expected [3, 4]. In this regard, the question becomes relevant "greening" and "ecologization" of pest control, i.e. maximum consideration of natural laws and the most remote effects of certain methods of struggle. Priority for the strategy in the XXI century would be environmentally friendly and safety practices. Such a practice was needful and became necessary. This fact was underlined by decisions and suggestions of meetings of United Nations and last conference "Rio + 20" "The future we want" [5]. These perspective methods we mean reproducing the processes occurring in nature without human intervention. In this paper I attempt classification of environmentally friendly pest control methods in order to develop effective strategies to reduce the number of pests at urban area. The first basis of classification - the laws of ecology developed by V. Vernadsky, G. Gauze and other scientists [3 - 6]. Second base - applied research aimed at combating pests, reported at the congresses ICUP $[2,7]$ International Congresses of Urban Pests and other international meetings.

\section{Theoretical Background of Classification and Examples}

Environmentally-friendly methods divide into 4 main groups, within each of which has its own version of the methodology - see figure: 


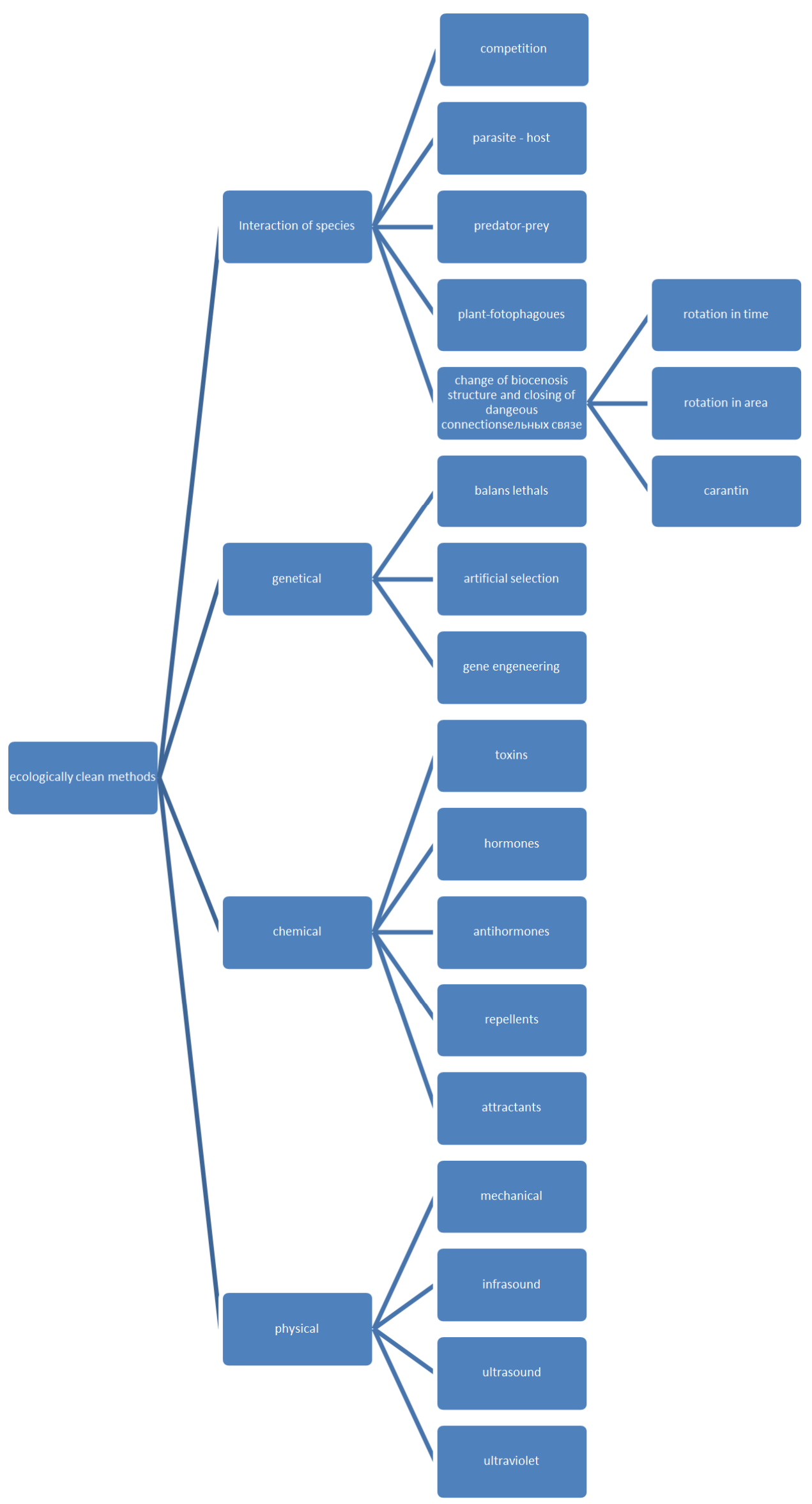

Figure 1. Classification of ecologically clean methods of struggle with pests. 
1. Proper environmental practices or methods of interspecific relationships.

3. Genetical.

2. Chemical.

4. Physical.

All the conditions and processes that use these methods, in one form or another are present in nature. Methods of interspecies relationships (or proper environmental practices) model fundamental natural laws. It is well known [6] that the most severe form of interspecies relationships, which can lead to complete displacement of the population of any species is competition. The most practical method of dealing in this case - to check the ecological niche of species competing with the pest, but less harmful.

\section{Results}

Host-parasite system was and is widely used in pest control [8-10]. Pest infestation by viruses, bacteria, worms, is widely practiced in the practice of struggle. Particularly intensively used insect is Trichogramma (Trichogramma, Hymenoptera), affecting larvae of many insect pests. Predator-prey system also is widely used in pest control, especially insects. Thus, to reduce the number of aphids feeding on them are widely used - beetles Coccinellidae. One of the most developed methods of controlling harmful plants is the introduction of phytophagous insects. Such efforts for several years succeeded in Stavropol Territory (South Russia) clear large areas overgrown quarantine weed ambrosia - Ambrosia artemisiifolia - due to the introduction of American beetle phytophage - Zygogramma suturalis [11].

Under environmentally friendly methods can be understood change biocenosis structure and the elimination of unwanted connections. The traditional practice of seed farming violates principles of ecological balance and diversity, where a large area is sown with one species of plants. In a given area will inevitably come weeds, pests and phytophags. To limit their spread may alternation of crops in time (regular change cultures) and in space - the alternation between different fields of crops. Finally, these same methods should include quarantine, i.e. limit unwanted transfers of animals and plants.

Genetic methods can only be based on knowledge of genetics common objects to be [16]. In the 30s years of the last century Russian scientist A. S. Serebrovsky [17] productive contacts with individuals of the wild population, they saturate it with lethal genes. Passing in the homozygous state, lethal genes reduce the number of unwanted populations in the medium type. This method is used in Russia, then attempted in recent years in Brazil [18, 7]. Its efficiency is not very high. In accordance with the laws of natural homeostasis and natural selection, the population quickly exempt from alien lethal and semi lethal genes [7]. But under composition with other methods, the use of this method is appropriate.
Methods of selection - genetic and genetic engineering, based on knowledge of genetics private facilities [19 21, 12], aimed at getting new breeds and varieties of species resistant to pests. Another direction - increasing virulence of species used for pest control in systems "predator-prey", "phytophagous - plant", "host-parasite".

Chemical control methods are widespread and are the main on this day. But the use of pesticides first generations - alien nature toxic substances - had too many negative environmental $[22,23]$. We consider in this case the use of only those substances that are inherent in nature. Foremost they are the biological toxins that are derived from bacteria [20]. Over the years, applied and continue to apply insecticides - juvenile hormone analogues insects. This method is relatively environmentally friendly, although when released into the environment of these substances exhibit properties of weak [15]. At the end of the last century, has attracted the attention of entomologists azodirahta tropical plant (Azadirachta sp.), containing a substance with properties azodirahtin antihormone the ability to suppress the activity of insect hormone ecdysone (http://rupest.ru>PPDB $>$ azadirachtin.html) [25]. However, these works have not been developed. Just a number of environmentally friendly methods include the use of repellents to attract pests and further disappearance. It also adjoins the use of attractants for the purpose of repelling pests $[21,26]$.

Physical methods of pest control based on the use of physical processes and fields present in the world around us. These methods are developed recently and not been widely used [3, 22, 27]. In a sense, the physical methods include mechanical methods and long practiced in agriculture. So, strong rain flows can wash aphid clones from the trees. Accordingly, the processing plants attacked by aphids, strong streams of water may already be considered as an environmentally friendly physical method. It is known that against such a formidable pest of potato fields, such as the Colorado potato beetle, only a relatively efficient method is again hand-picking.

Perspective and knowledge-based techniques is the use of acoustic and electromagnetic fields [3]. At high pressure ultrasound and infrasound have negative effects on many organisms. In the area of generating high-power ultrasound (e.g., proximity to airfields) mammals rodents leave or die. Ultrasound has a negative effect for Insects, disrupting their reproductive cycles. Ultraviolet radiation can have on pests like attractant action and lethal [19].

\section{Conclusion}

The twenty-first century has created many environmental problems for humanity. They are related to climate dynamics, the spread of undesirable animals, plants, and microorganisms, and the negative impact of humanity on these processes. The forces of the biosphere are more important for the evolution of the Earth than the influence of humanity. Non-biological 
processes are more energetically significant than processes of biological and social Genesis. Man cannot radically change the ecological situation on Earth, despite all the progress of scientific and technological progress. He must understand that nature is stronger than he is. The right way of development is not to struggle with nature, but to be in harmony with it. The solution of environmental problems should take into account the laws that work independently of the person. Accounting should be based on knowledge of natural Sciences. The level of this knowledge is high enough to ensure sustainable development.

With the increasing human pressure on nature, increasing climate variability [1] and an active attack of pests urbanized biocenosis, special urgency pest with minimal environmental consequences and not harmful to humans. The basis of those methods is based on imitation of the processes that have already taken place in nature. Given the high adaptive properties of pest populations, need constant rotation and change of control methods.

\section{References}

[1] Sapunov, V. B. 2012. Theoretical basis of pest management // Integrated pest management. $7^{\text {th }}$ Intern Symp, Memphis, Tennessee, March 27 - 29, p. $100-101$.

[2] Sapunov, V. B. 2013. Theoretical basis of pest management // Ecological chemistry, V. 22, \#. 1, c. $48-58$.

[3] Sapunov, V. B., Legkov, V. V., 1995. Effect of ultrasonic treatment on development of Drosophila eggs // Insects: Chemical, physiological and environment aspects. Wroclaw, Wroclaw Univ., p. 333- 337.

[4] Sapunov, V. B. 2012. $7^{\text {th }}$ International Integrated Pest Management Symposium // Pest management, №1, p. 45 - 47. (Russ.).

[5] Towards a green economy: pathways to sustainable development and poverty eradication. - Nairobi (Kenia), Geneva (Switzerland): UNEP, 2011. 626 p.

[6] Gause, G. 1934. Struggle for existence. N. Y., A. P.

[7] Sapunov, V. B. 2011. $7^{\text {th }}$ International Conference on Urban pest). Pest management, №3, p. 54-57. (Russ).

[8] Hu, X. P. 2008. Starvation associated mortality, cannibalism, body weight and intestinal symbiotic protist profile of Reticuliter mesftavipes // Proc. $6^{\text {th }}$ Int Conf Urban pests. Budapest, p. $367-371$.

[9] Lenz, M., 2005. Biological control of termite management: the potential of nematodes and fungal pathogens // Proc. $5^{\text {th }}$ Int Conf Urban pests. Singapore, p. 47 - 52.

[10] Rafinejad, D., Shyan, A., Tigary, S. et. al. 2005. Parasitic arthropods of rodents in Khoramabad-Lorestan, Iran // Proc. $5^{\text {th }}$ Int Conf Urban pests. Singapore, p. 363 - 369.

[11] Sapunov, V. B., Belokobylsky, S. A., 1989. Phenetical structure of population of ragweed fagous Zygogramma suturalis (Coleoptera, Chrysomelidae) in Stavropol region //
Theoretical basis of struggle with ragweed. L-d, Nauka, p. 166 - 172. (Russ.).

[12] Lee, C-Y., Forscher, B. T., Jenkins, T. M., 2005. Taxonomic questions on Malaysian termites (Isoptera, Termitidae) answered with morphology and DNA biotechnology // Proc. $5^{\text {th }}$ Int Conf Urban pests. Singapore, p. $205-211$.

[13] Sapunov, V. B. 2011. Termite population dynamics and their role in dry wood destruction and green house gases production // Proc. $7^{\text {th }}$ Int Conf Urban pests, Ouro Preto (Brazil), p. 395.

[14] Sapunov, V. B. 2011. Phenogenetic indication as a method of assay of urban area ecological state // Proc. $7^{\text {th }}$ Int Conf Urban pests, Ouro Preto (Brazil), p. 409.

[15] Slama, K. 1999. The history and current status of juvenoids. Proc. $3^{\text {th }}$ Int Conf Urban pests. Prague, p. 9-26.

[16] Vargo, E. 2011. How genetic study can help with subterranean termite management // Proc. $7^{\text {th }}$ Int Conf Urban pests. Ouro Preto, p. $7-12$.

[17] Serebrovsky, A. S. 1935 Animal hybridization. L-d - Moscow, Biomedgiz, 290 p. (Russ.).

[18] Zia Siddiqi. 2011. Global Food Safety Initiative and its Impact on Pest Management Programs in North America // Proc. $7^{\text {th }}$ Int Conf Urban pests. Ouro Preto, p. 367 - 371.

[19] Hogsette, J. A. 2008. Ultraviolet light traps: design affect attraction and capture // Proc. $6^{\text {th }}$ Int Conf Urban pests. Budapest, p. 193 - 196.

[20] Ignatowicz, S., Swietoslawski, J. 1999. Efficacy of pheromone and poison baits and their use in the integrated control of house fly // Proc. $3^{\text {th }}$ Int Conf Urban pests. Prague, p. 628.

[21] Jahangir, K., Lee, C-Y., Zairi, J. 2008. Effect of sugar and animal blood availability on attraction of Aedes spp. to humans // Proc. $6^{\text {th }}$ Int Conf Urban pests. Budapest, p. 197 201.

[22] Chen, Z., White, M. S., Robinson, W. H. 2005. Low pressure vacuum to control larvae of Hylotrupesbajulus (Coleoptera, Cerambicidae) // Proc. $5^{\text {th }}$ Int Conf Urban pests. Singapore, p. $325-329$.

[23] Francesli Adriana Gusmao, Neiva Sibinel, Bajomi, D., Ana Eugenia Campos-Farinha. 2008. Tramp ant species control with methopren in Brazil // Proc. $6^{\text {th }}$ Int Conf Urban pests. Budapest. P. 71 - 75.

[24] Scharf, M. E., Zhou, X. G., Benett, G. W. 2005. Application of molecular genomic in addressing questions on termite biology // Proc. $5^{\text {th }}$ Int Conf Urban pests. Singapore, p. $19-27$.

[25] http://rupest.ru>PPDB>azadirachtin.html.

[26] Ortencio Filho, H. 2011. Bats in natural and urban development // Proc. $7^{\text {th }}$ Int Conf Urban pests. Ouro Preto, p. $13-16$.

[27] Sapunov Valentin. Real need of the world in food. A future of agricultural production // Handbook of research on globalized agricultural trade and new challenges for food security. IGI Global, Hersky PA, USA, 2020, Chapter 1, p. 1-12. 